\title{
Presiden RI Hasil Pilpres 2019
}

Oleh Shohibul Anshor Siregar

"To Build The World A New" adalah judul pidato Presiden RI Soekarno di depan Sidang Umum PBB ke-XV tanggal 30 September 1960.Pidato itu dimulai bukan dengan basa-basi. Bukan dengan ketiadaan latar belakang pengetahuan, sejarah, geopolitik, wawasan dan semangat juang. Melainkan ketegasan sikap yang amat nalar dan dengan diplomasi serta komunikasi substantif. Jangan pernah ragukan kemampuan bahasa dan retorika Soekarno dan tak satu pun orang di Indonesia yang merasa perlu mengelu-elukan itu sebagai sebuah keungguolan karena memang sudah seharusnya demikian untuk seorang pemimpin dari sebuah bangsa yang besar.

"Saya merasa tertekan oleh suatu rasa tanggung-jawab yang besar....Saya telah memanjatkan do'a kepada Tuhan Yang Maha Kuasa agar lidah saya dapat menemukan kata-kata yang tepat untuk menyatakan perasaan hati saya, dan saya juga telah berdo'a agar kata-kata ini akan bergema dalam hati sanubari mereka yang mendengarnya".

Anda tahu tidak banyak negara di dunia ini yang di dalam konstitusinya dinukilkan ketegasan tanggungjawab negara-bangsa itu untuk tata dunia yang adil dan berkeadilan. Indonesia ada pada posisi penegasan itu.Indonesia harus besar. Harus kuat. Harus Cerdas. Harus tangguh. Harus unggul. Karena tanpa semua predikat itu tak akan mampu menjadi dirinya sendiri sebagaimana diminta oleh konstitusi.

Jangan pula lupa, Indonesia di bawah kepemimpinan Soekarno pernah keluar dari keanggotaan badan dunia itu, yakni pada tanggal 7 Januari 1965. Sekretaris Jenderal PBB ketika itu, U Thant,tak bisa memberi respon apakah keputusan Seokarno sah dan bagaimana sikap yang harus diambil PBB.Aturan dalam Piagam PBB menyatakan bahwa Majelis Umum memiliki kekuatan untuk mengeluarkan negara anggota atas alasan tak patuh pada aturan. Itu tidak identik dengan kasus jika sebuah negara keluar secara sukarela.

Belakangan diketahui bahwa dalam suratnya kepada Menteri Luar Negeri RI Dr. Soebandrio, $U$ thant menyatakan bahwa dirinyasangat menyesalkan keputusan Indonesia. Hal itu terbaca dari laporan tahunan bulan September 1965.Di sana U Thant menulis:"Saya berharap keputusan Sukarno hanyalah fase temporer dan karena itu untuk jangka pajang Indonesia dapat dilayani dengan sebaik-baiknya dengan melanjutkan keanggotaan dan dengan berpartisipasi sepenuhnya dalam kegiatan organisasi yang konstruktif."

Masih dalam bagian pembukaan, pidato Soekarno setebal 70 halaman naskah itumenyerukan "Kitab Suci Islam mengamanatkan sesuatu kepada kita pada saat ini. Qur’an berkata: Hai, sekalian manusia, sesungguhnya Aku telah menjadikan kamu sekalian dari seorang lelaki dan seorang perempuan, sehingga kamu berbangsa-bangsa dan bersuku-suku agar kamu sekalian kenal-mengenal satu sama lain. Bahwasanya yang lebih mulia diantara kamu sekalian, ialah yang lebih taqwa kepadaKu”.

Retorika Soekarno menarik garis dengan klaim bahwa ia berbicara atas nama 92 juta rakyat Indonesia yang telah mengalami hidup penuh dengan perjuangan dan pengorbanan, membangun suatu Negara diatas reruntuhan suatu imperium, bagian dari rakyat Asia dan Afrika, sambil mengkonfrontasikan dengan rakyat dari benua Amerika dan Eropa serta Australia. Semua berharap PBB dapat memberi sesuatu harapan masadepan dan suatu kemungkinan elok.

Review sejarah dalam pidato Soekarno tiba pada pesan kuat untuk menghargai kebangkitan nasionalisme baru seiring tata baru yang terus berkembang ke arah mengakhiri kesewenang-wenangan menguasai atas nama penjajahan oleh satu ke lain negara. Soekarno memaksakan keyakinannya bahwa bila perjalanan menuju kebebasan itu sudah selesai diseluruh dunia, maka dunia akan menjadi suatu 
tempat yang lebih baik; akan merupakan suatu tempat yang lebih bersih dan jauh lebih sehat. Dunia tidak boleh berhenti berjuang, karena telah berjanji kepada masa-depan dan itu harus dipenuhi, bukan untuk kepentingan sendiri, melainkan untuk kepentingan umat manusia seluruhnya.

Dunia masih ingat bahwa 5 tahun sebelumnya, di Bandung, diadakan Konferensi Asia Afrika (KAA) yang menghasilkan Dasa Sila Bandung. KAA meminta dunia agarpertama, menghormati hak-hak dasar manusia dan tujuan-tujuan serta asas-asas yang termuat di dalam piagam PBB.Kedua, menghormati kedaulatan dan integritas teritorial semua bangsa. Ketiga, mengakui persamaan semua suku bangsa dan persamaan semua bangsa, besar maupun kecil.Keempat, tidak melakukan campur tangan atau intervensi dalam soalan-soalan dalam negeri negara lain.

Kelima, menghormati hak setiap bangsa untuk mempertahankan diri sendiri secara sendirian mahupun secara kolektif, yang sesuai dengan Piagam PBB. Keenam, tidak menggunakan peraturan-peraturan dan pertahanan kolektif untuk bertindak bagi kepentingan khusus dari salah satu negara-negara besar, tidak melakukan campur tangan terhadap negara lain.Ketujuh, tidak melakukan tindakan ataupun ancaman agresi maupun penggunaan kekerasan terhadap integritas teritorial atau kemerdekaan politik suatu negara.

Kedelapan, menyelesaikan segala perselisihan internasional dengan cara damai, seperti perundingan, persetujuan, arbitrasi, atau penyelesaian masalah hukum ataupun lain-lain cara damai, menurut pilihan pihak-pihak yang bersangkutan, yang sesuai dengan Piagam PBB.Kesembilan, memajukan kepentingan bersama dan kerjasama, Kesepuluh, menghormati hukum dan kewajiban-kewajiban internasional.

Soekarno secara terang-terangan menyerang PBB sebagai lembaga dunia yang gagal menciptakan perdamaian, bahkan curiga piagam PBB sudah ketinggalan zaman.Tetapi hingga hari ini PBB tetap tak berubah. Secara struktural lebih mengabdi kepada kepentingan negara-negara besar sembari mencari retorika dan legitimasi untuk hasrat penguasaan dengan model baru.

Mungkin Fidel Castro adalah pemimpin negara dengan pidato terpanjang di PBB. Para jurnalis mencatat spesifik bahwa untuk mengeritik AS, Castro menghabiskan waktu 4,5 jam, dan salah satu kalimatnya yang tak mungkin dilupakan dunia ialah "Jika Kennedy bukan seorang yang jutawan buta huruf dan bodoh, ia akan mengerti bahwa tidak mungkin untuk meletuskan revolusi pemilik tanah terhadap petaninya. Mungkin itu yang kemudian menjadikannya terpilih dan mengalahkan Nixon".

Pada tahun 1987 Presiden Nikaragua, Daniel Ortega, juga mengeritik hegemoni AS di kawasan Latin dan Karibia dalam forum PBB. Katanya: "Ingat Presiden Reagan, Rambo hanya ada di Film-film". Hugo Chavez, Presiden Venezuela juga tercatat pernah melakukan gebrakan dengan terang-terangan menyatakan diri sebagai anti AS karena imperialisme AS sangat membahayakan berlangsungan spesies manusia.

Pada bulan September 2009 Muammar Khadafi sebetulnya hanya dijadawalkan berpidato 15 menit dalam sidang Majelis Umum PBB.Namun akhirnya lebih dari satu jam, dan di sela pidatonya merobekrobek salinan piagam PBB sembari menuduh Dewan Keamanan PBB menjadi organisasi yang identik teroris al-Qaeda.Suaranya amat langka sepanjang sejarah tentang tuntutan reparasi 7,7 triliun dolar AS sebagai kompensasi yang harus dibayar ke Afrika oleh para penguasa kolonial masa lalu. Indonesia yang dibodoh-bodohi dalam Konferensi Meja Bundar (membayar kerugian Perang yang diderita oleh Belanda yang jumlahnya sangat besar dan pelunasannya baru dapat dilakukan tahun 2003) sama sekali tak pernah berbicara hal serupa, meski beroleh pampasan dari Jepang yang karena jumlahnya cukup besar akhirnya dicicil selama 12 tahun.

Konon salinan pidato Mahmoud Ahmadinejad selalu diawasi, namun pada tahun 2011 yang lalu pidato Presiden Iran ini dengan pedas mengecam AS dan Barat sebagai kekuatan arogan yang 
mengandalkankeserakahan dan petualangan militer. "Siapa yang mendukung pemerintahan diktator militer di Asia, Afrika, dan Amerika Latin? Siapa yang menggunakan serangan 11 September sebagai alasan untuk menyerang Afganistan dan Irak? Siapa yang bertanggung jawab atas resesi ekonomi dunia?"Semua orang tahu bahwa Ahmadinejad memaksudkan Amerika Serikat.

Untuk kondisi tata dunia yang amat tidak adil hari ini, pidato Soekarno sangat penting khususnya ketika ia berkata "oposisi kami terhadap kolonialisme dan imperialisme timbul baik dari hati maupun dari kepala kami. Kami menentangnya atas dasar kemanusiaan, dan kami menentangnya pula dengan alasan bahwa hal ini merupakan suatu ancaman yang besar dan makin besar lagi terhadap perdamaian. Tiadanya persesuaian pendapat dengan kekuatan-kekuatan kolonial berkisar pada soal-soal waktu dan keamanan, karena sekarang setidak-tidaknya mereka beromong-kosong tentang cita-cita kemerdekaan nasional".

Untuk harga sebuah kedaulatan, hingga kapan pun, pidato Soekarno patut menjadi pelajaran untuk bangsa ini dan bangsa-bangsa senasib di permukaan bumi ketika ia berkata tegas, dan bukan menggertak: "Belum lama berselang tentara di Irian Barat yang masih muda serta tersesat itu dan yang membela suatu faham yang telah ketinggalan zaman, diperkuat dengan datangnya kapal induk Karel Doorman dari tanah airnya yang jauh itu. Maka saatitulah keadaan menjadi betul-betul berbahaya. Kepala Staf Angkatan Darat Indonesia duduk dalam delegasi saya ini, Jenderal Nasution. la adalah prajurit profesional yang ulung, seperti halnya dengan anak buah yang dipimpinnya, dan seperti juga halnya dengan bangsa yang dibelanya. la pertama-tama adalah seorang yang cinta damai. Tetapi lebih daripada itu, ia dan anak buahnya serta bangsa saya mengabdi untuk mempertahankan tanah air kami”.

Pidato Soekarnolainnya yang pernah disampaikan pada tanggal 28 Maret 1963, yang mengklaim diri sebagai Presiden/Panglima Tertinggi Angkatan Perang Republik Indonesia, menegaskan tekad bangsa untuk menanggulangi secara keseluruhan dengan kekuatan sebulat-bulatnya persoalan ekonomi nasional.

Berdasarkan strategi dasar ekonomi Indoneisa,Soekarno menegaskan, maka dalam tahap pertama kita harus menciptakan susunan ekonomi yang bersifat nasional dan demokratis, yang bersih dari sisa-sisa imperialisme dan bersih dari sisa-sisa feodalisme, dan merupakan bangun ekonomi tanpa penghisapan manusia oleh manusia (exploitation de l'homme par'homme).

Mungkin para ekonom sekarang dan para pembijaksana pemerintahan sudah benar-benar tak apresiatifterhadap Soekarno dan menganggapnya tidak realistis ketika berkata bahwa yang harus diselenggarakan sekarang ialah memperbesar produksi berdasarkan kekayaan alam yang berlimpahlimpah dan meletakkan dasar-dasar untuk industrialisasi. Harus disadari bahwa modal terpenting bagi pembangunan nasional ialah menggali dan mengolah alam kita itu. Ini berarti bahwa kita harus mengutamakan pertanian dan perkebunan, kita harus mementingkan pertambangan, yang tentunya hanya dapat memberikan hasil sebesar-besarnya jika dikerjakan atas dasar kegotong-royongan antara massa rakyat dan Pemerintah, sebagai syarat untuk menimbulkan dan menyalurkan daya kerja dan daya kreatif rakyat maksimal.

Kita sadar, kata Soekarno, bahwa "sisa-sisa kolonial dan sisa feodal dan demikian pula sifat-sifat hubungan ekonomi dan perdagangan dengan dunia luar masih juga memberikan rintangan...."

Sebuah kecurigaan besar tak dapat ditutupi ketika menelaah orientasi partai-partai yang bersitegang di balik pengusungan dua pasang Capres. Kebanyakan pidato merekaadalah pernyataan hasrat beroleh kemakmuran bagi diri dan kelompoknya. Itu sangat mudah diketahui meski mereka berusaha menyembunyikannya dengan cara-cara yang khas. 
Prasyarat apakah yang mungkin dipermodalkan saat ini untuk memajukan Indonesia dengan arsitektur ekonomi dan pembangunan yang sesuai kehendak konstitusi? Di sinilah para negarawan di luar kelembagaan politik menangis.

Konstitusi yang sudah diamandemen hingga 4 kali sudah merombak jati diri bangsa dengan ketakmungkinan beroleh peluang terbaik di tengah neoliberalisasi sambil dikendalai oleh banyaknya UU yang menjadi turunannya bersifat memusuhi kepentingan mayoritas rakyat. Negarawan di luar kelembagaan politik sama sekali tidak sedang mengekspresikan kecengengan ketika mereka sangat waswas bangsa ini menjadi budak di negeri sendiri.

Saya pribadi melihat suksesi tak menjamin perubahan, karena hanya menjadi sebuah ritual menawarkan pergiliran kekuasaan di antara para penggantang kekuasaan belaka. Sedikit harapan muncul jika sebuah anjuran kepada seluruh rakyat dapat efektif: "fahami masalah negara-bangsamu, tentukan pilihan kepada pasangan yang paling sedikit mudharatnya bagi negara-bangsa; lakukan hal yang sama dalam menentukan pilihan atas caleg untuk semua level (DPRD Kabupaten, Kota, Provinsi, Pusat dan DPD)".

Penulis dosen FISIP UMSU. Koordinator Umum Pengembangan Basis Sosial Inisiatif \& Swadaya ('nBASIS). 